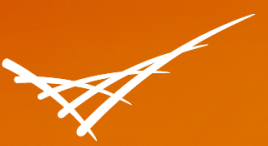

Pacific Northwest

NATIONAL LABORATORY

\title{
Analysis of Pharmaceutical and Personal Care Compounds in Wastewater Sludge and Aqueous Samples using GC-MS/MS
}

\section{March 2016}

\section{Zhong}

AV Mitroshkov

TJ Gilmore 


\title{
DISCLAIMER
}

This report was prepared as an account of work sponsored by an agency of the United States Government. Neither the United States Government nor any agency thereof, nor Battelle Memorial Institute, nor any of their employees, makes any warranty, express or implied, or assumes any legal liability or responsibility for the accuracy, completeness, or usefulness of any information, apparatus, product, or process disclosed, or represents that its use would not inf ringe privately owned rights. Reference herein to any specific commercial product, process, or service by trade name, trademark, manufacturer, or otherwise does not necessarily constitute or imply its endorsement, recommendation, or favoring by the United States Government or any agency thereof, or Battelle Memorial Institute. The views and opinions of authors expressed herein do not necessarily state or reflect those of the United States Government or any agency thereof.

\author{
PACIFIC NORTHWEST NATIONAL LABORATORY \\ operated by \\ BATTELLE \\ for the \\ UNITED STATES DEPARTMENT OF ENERGY \\ under Contract DE-AC05-76RL01830
}

This document was printed on recycled paper. 


\section{Analysis of Pharmaceutical and Personal Care Compounds in Wastewater Sludge and Aqueous Samples using GC-MS/MS}

March 2016

L Zhong

AV Mitroshkov

TJ Gilmore

Prepared for

the U.S. Department of Energy

under Contract DE-AC05-76RL01830

Pacific Northwest National Laboratory

Richland, Washington 99352 



\section{Executive Summary}

The Bioenergy Program at Pacific Northwest National Laboratory (PNNL) is evaluating the feasibility of converting wastewater sludge materials to fuels. Wastewater sludge from various municipalities will be used in the evaluation process and as with any municipal waste, there is the potential for residual contaminates to remain in the sludge following wastewater treatment. Many surveys and studies have confirmed the presence of pharmaceuticals in municipal wastewater and effluents (World Health Organization, 2011). Determination of the presence and concentrations of the contaminants is required to define the proper handling of this sludge in laboratory research.

A list of targeted compounds was acquired from the literature and an analytical method was developed for the pharmaceutical and personal care compounds. The presence of organics complicated the analytical techniques and, in some cases, the precision of the results. However, residual concentrations of a range of compounds were detected in the wastewater sludge and the presence and concentrations of these compounds will be considered in identifying the appropriate handling of this material in conduct of research. 



\section{Acknowledgments}

The authors acknowledge the financial support from the Processing and Manufacturing Technologies Project Management Office to conduct this study. 



\section{Acronyms and Abbreviations}

MRM

MSTFA

MW

PNNL

PPE

SIM
Multiple reactions monitoring

N-Methyl-N-(trimethylsilyl)trifluoroacetamide

Molecular Weight

Pacific Northwest National Laboratory

personal protective equipment

selected ion monitoring 



\section{Contents}

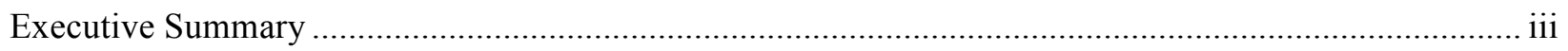

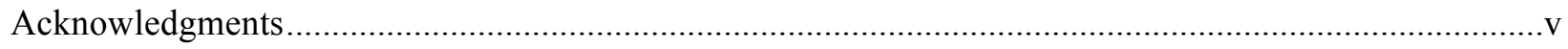

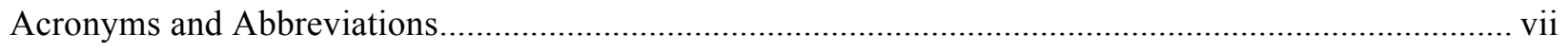

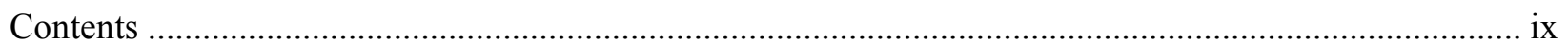

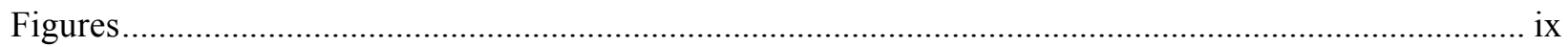

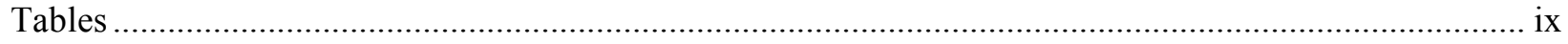

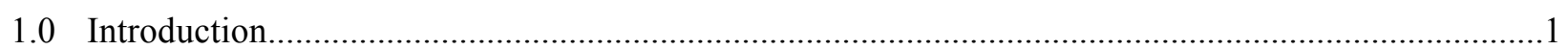

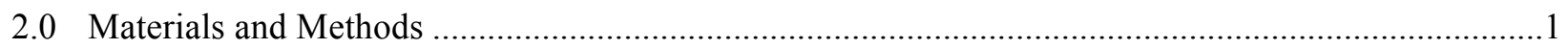

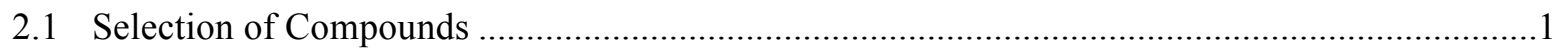

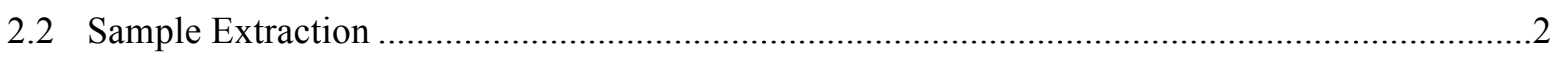

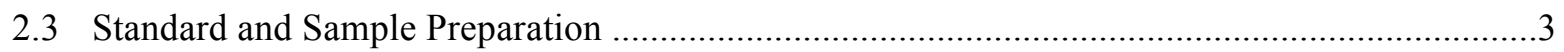

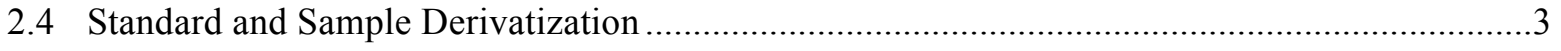

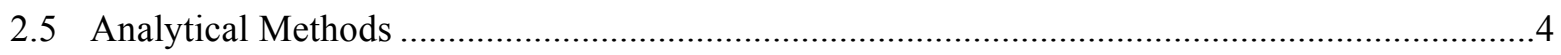

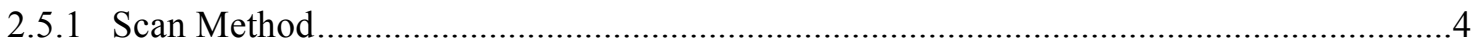

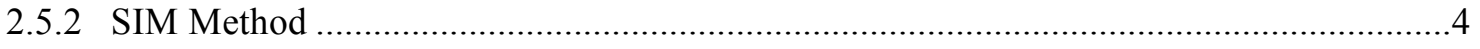

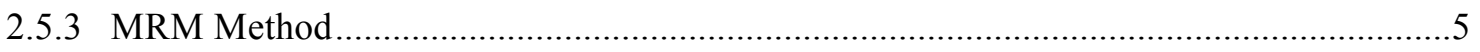

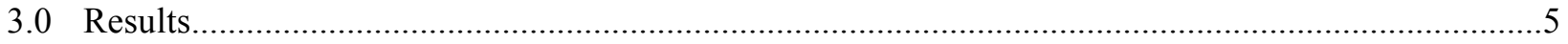

$4.0 \quad$ Summary

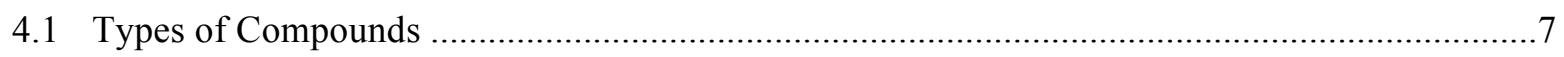

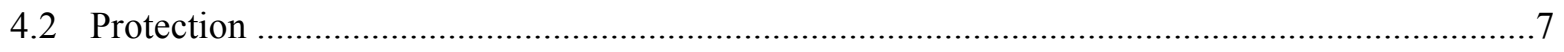

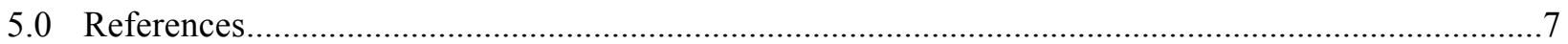

\section{Figures}

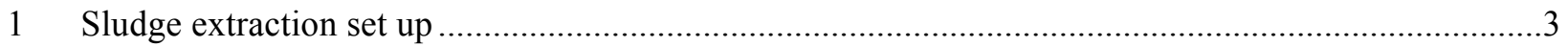

2 Extracting vials after centrifugation paired with separated extractant..............................................

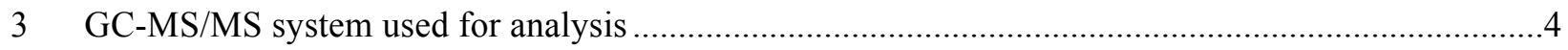

\section{Tables}

1 Descriptions of seven sludge sample and three aqueous samples .................................................

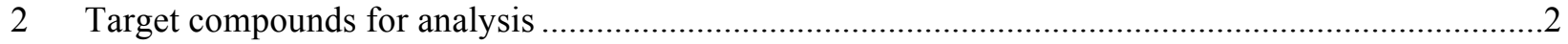

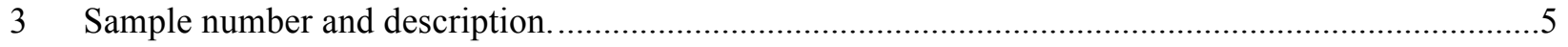





\subsection{Introduction}

Wastewater sludge can be used as feedstock for fuel conversion and the Bioenergy Program at Pacific Northwest National Laboratory (PNNL) is evaluating the feasibility of this conversion. Wastewater sludge from various cities will be used in the evaluation process. As with any municipal waste, there is the potential for residual contaminates to remain in the sludge following wastewater treatment. The determination of the presence and concentrations of the contaminants is required to define the proper handling of this waste water sludge in laboratory research.

Wastewater sludge was received from two different wastewater-treatment plants to determine the presence of pharmaceutical compounds and to quantify their concentrations, an extraction procedure and an analytical method were developed for the pharmaceutical and personal care compounds. Seven sludge samples and three aqueous samples (Table 1) have been processed. The sludge samples S-1 through S-5 were collected from homogenized/well mixed batches ( $\sim 20 \mathrm{~kg}$ batches). Samples S-6 and S-7 were grab sample collected from approximately $20 \mathrm{~kg}$ of digested sludge, before homogenization. Samples S-3 and S-4 are duplicate samples. S-6 and S-7 can also be considered independent subsamples collected from the same batch. The aqueous samples were collected from a byproduct stream generated in the fuel conversion process. Within the process, the sludge is heated $\left(350^{\circ} \mathrm{C}\right)$ at a pressure that maintains the sludge in a liquid phase. Outputs from the process include a crude oil and an aqueous byproduct.

Table 1. Descriptions of seven sludge sample and three aqueous byproduct samples

\begin{tabular}{ccccl}
\hline $\begin{array}{c}\text { Sample } \\
\text { No. }\end{array}$ & Matrix & $\begin{array}{c}\text { Approx } \\
\text { Mass, g }\end{array}$ & $\begin{array}{c}\text { Sample } \\
\text { Date }\end{array}$ & \multicolumn{1}{c}{$\begin{array}{c}\text { Descriptions of samples received at PNNL } \\
\text { between October 2014 and July 2015. }\end{array}$} \\
\hline S-1 & Wet Sludge & $\sim 30$ & $9 / 8 / 15$ & Autoclaved algae grown on effluent from the primary clarifier. \\
S-2 & Wet Sludge & $\sim 30$ & $9 / 8 / 15$ & Autoclaved algae grown on effluent from the primary clarifier. \\
S-3 & Wet Sludge & $\sim 30$ & $9 / 8 / 15$ & Autoclaved primary sludge. Sample (S-3) and duplicate (S-4). \\
S-4 & Wet Sludge & $\sim 30$ & $9 / 8 / 15$ & Autoclaved secondary sludge. \\
S-5 & Wet Sludge & $\sim 30$ & $9 / 8 / 15$ & Aut \\
S-6 & Wet Sludge & $\sim 30$ & $9 / 8 / 15$ & $\begin{array}{l}\text { Digested sludge, not homogenized. Sample (S-6) and duplicate } \\
\text { (S-7). }\end{array}$ \\
S-7 & Wet Sludge & $\sim 30$ & $9 / 8 / 15$ & $\begin{array}{l}\text { Hydrothermal liquefaction aqueous byproduct from conversion } \\
\text { on algae grown on primary clarifier effluent. }\end{array}$ \\
A-1 & Aqueous & 250 & $9 / 9 / 15$ & \\
A-2 & Aqueous & 250 & $9 / 9 / 15$ & $\begin{array}{l}\text { Hydrothermal Liquefaction aqueous byproduct from conversion } \\
\text { on primary sludge. This was ion exchanged before analysis. }\end{array}$ \\
A-3 & Aqueous & 250 & $9 / 9 / 15$ & $\begin{array}{l}\text { Hydrothermal liquefaction aqueous byproduct from conversion of } \\
\text { digested sludge. }\end{array}$ \\
\hline
\end{tabular}

\subsection{Materials and Methods}

\subsection{Selection of Compounds}

Thousands of compounds with a wide range of chemical structures are used in pharmaceutical products (Halling-Sorensen et al. 1998). Based on literature-reported gas chromatography-mass spectrometry (GCMS) analysis of pharmaceutical compounds (Togola and Budzinski 2007; Mottaleb et al. 2015) and the relevant compounds listed in a U.S. Environmental Protection Agency report on Targeted National 
Sewage Sludge Survey (EPA 2009), the chemicals listed in Table 2 were selected as the target compounds in this study.

Table 2. Target compounds for analysis

\begin{tabular}{|c|c|c|c|c|}
\hline Compound Name & CAS No. & Formula & MW & Class \\
\hline 17-alpha-Ethynylestradiol & $57-63-6$ & $\mathrm{C}_{20} \mathrm{H}_{24} \mathrm{O}_{2}$ & 296.40 & Hormone \\
\hline 17-beta-Estradiol & $50-28-2$ & $\mathrm{C}_{18} \mathrm{H}_{24} \mathrm{O}_{2}$ & 272.38 & Hormone \\
\hline 4-para-Nonylphenol & $84852-15-3$ & $\mathrm{C}_{15} \mathrm{H}_{24} \mathrm{O}$ & 220.35 & Steroid \\
\hline 4-tert-Octylphenol & $140-66-9$ & $\mathrm{C}_{14} \mathrm{H}_{22} \mathrm{O}$ & 206.32 & Other drugs \\
\hline Acetaminophen & $103-90-2$ & $\mathrm{C}_{8} \mathrm{H}_{9} \mathrm{NO}_{2}$ & 151.16 & Other drugs \\
\hline Bis-phenol A & $80-05-7$ & $\mathrm{C}_{15} \mathrm{H}_{16} \mathrm{O}_{2}$ & 228.29 & Hormone-like \\
\hline Caffeine & $58-08-2$ & $\mathrm{C}_{8} \mathrm{H}_{10} \mathrm{~N}_{4} \mathrm{O}_{2}$ & 194.19 & Other drugs \\
\hline Carbamazepine & $298-46-4$ & $\mathrm{C}_{15} \mathrm{H}_{12} \mathrm{~N}_{2} \mathrm{O}$ & 236.27 & Other drugs \\
\hline Ciprofloxacin HCL & $86393-32-0$ & $\mathrm{C}_{17} \mathrm{H}_{18} \mathrm{FN}_{3} \mathrm{O}_{3} \cdot \mathrm{HCl}$ & 385.82 & Antibiotics \\
\hline Diclofenac sodium salt & $15307-79-6$ & $\mathrm{C}_{14} \mathrm{H}_{10} \mathrm{Cl}_{2} \mathrm{NNaO}_{2}$ & 318.13 & Other drugs \\
\hline Erythromycin USP & $114-07-8$ & $\mathrm{C}_{37} \mathrm{H}_{67} \mathrm{NO}_{13}$ & 733.9 & Antibiotics \\
\hline Estrone & $53-16-7$ & $\mathrm{C}_{18} \mathrm{H}_{22} \mathrm{O}_{2}$ & 270.37 & Hormone \\
\hline Fluoxetine $\mathrm{HCl}$ & $56296-78-7$ & $\mathrm{C}_{17} \mathrm{H}_{18} \mathrm{~F}_{3} \mathrm{NO} \cdot \mathrm{HCl}$ & 345.79 & Other drugs \\
\hline Gemfibrozil & $25812-30-0$ & $\mathrm{C}_{15} \mathrm{H}_{22} \mathrm{O}_{3}$ & 250.3 & Other drugs \\
\hline Ibuprofen & $15687-27-1$ & $\mathrm{C}_{13} \mathrm{H}_{18} \mathrm{O}_{2}$ & 206.28 & Other drugs \\
\hline Naproxen & $22204-53-1$ & $\mathrm{CH}_{3} \mathrm{OC}_{10} \mathrm{H}_{6} \mathrm{CH}\left(\mathrm{CH}_{3}\right) \mathrm{CO}_{2} \mathrm{H}$ & 230.26 & Other drugs \\
\hline Ofloxacin & $82419-36-1$ & $\mathrm{C}_{18} \mathrm{H}_{20} \mathrm{FN}_{3} \mathrm{O}_{4}$ & 361.37 & Other drugs \\
\hline Primidone & $125-33-7$ & $\mathrm{C}_{12} \mathrm{H}_{14} \mathrm{~N}_{2} \mathrm{O}_{2}$ & 218.25 & Other drugs \\
\hline Progestrone & $57-83-0$ & $\mathrm{C}_{21} \mathrm{H}_{30} \mathrm{O}_{2}$ & 314.46 & Hormone \\
\hline Sulfamethoxazole & $723-46-6$ & $\mathrm{C}_{10} \mathrm{H}_{11} \mathrm{~N}_{3} \mathrm{O}_{3} \mathrm{~S}$ & 253.28 & Antibiotics \\
\hline Testosterone & $58-22-0$ & $\mathrm{C}_{19} \mathrm{H}_{28} \mathrm{O}_{2}$ & 288.42 & Hormone \\
\hline Triclosan & $3380-34-5$ & $\mathrm{C}_{12} \mathrm{H}_{7} \mathrm{Cl}_{3} \mathrm{O}_{2}$ & 289.54 & Antibiotics \\
\hline Trimethoprim & $738-70-5$ & $\mathrm{C}_{14} \mathrm{H}_{18} \mathrm{~N}_{4} \mathrm{O}_{3}$ & 290.32 & Antibiotics \\
\hline
\end{tabular}

\subsection{Sample Extraction}

Methylene chloride $\left(\mathrm{CH}_{2} \mathrm{Cl}_{2}\right)(>99.9$ percent) was used as the extractant for the pharmaceutical compounds from the sludge and water samples. For the sludge samples, $5 \mathrm{~g}$ of sludge was extracted using $20 \mathrm{ml}$ of $\mathrm{CH}_{2} \mathrm{Cl}_{2}$ for 48 hours. For the aqueous samples, $100 \mathrm{ml}$ of sample was extracted using $10 \mathrm{ml}$ of $\mathrm{CH}_{2} \mathrm{Cl}_{2}$ for 48 hours. In each case, the extractant and sample were mixed using a rotational mixer (Figure 1) and then centrifuged to separate the extractant. The extractant from each sample was then transferred to a vial for further processing and analysis (Figure 2). 


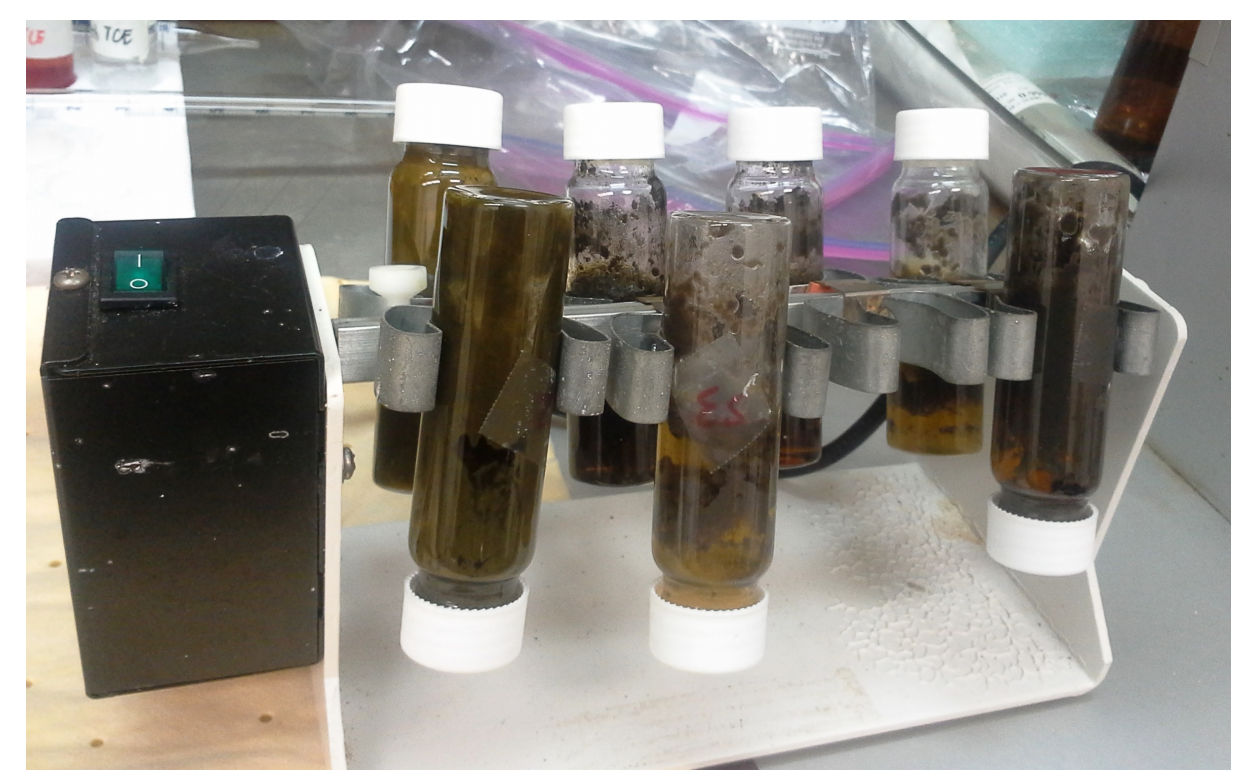

Figure 1. Sludge extraction set up.

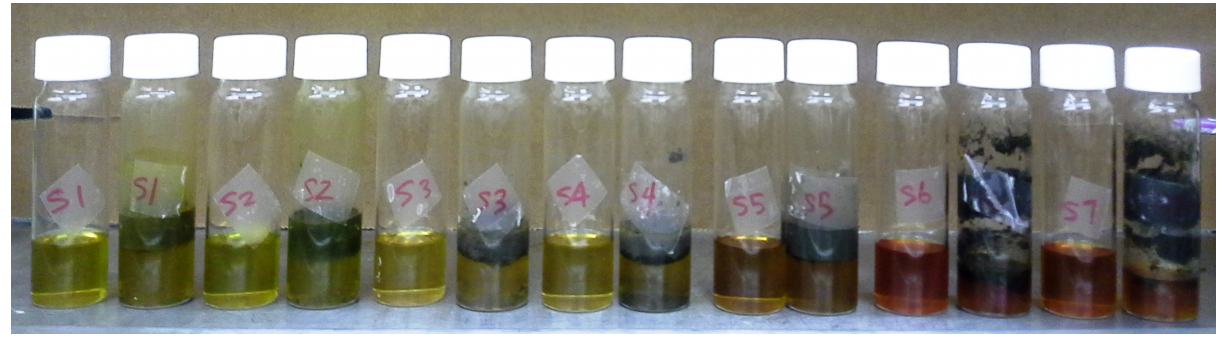

Figure 2. Extracting vials after centrifugation paired with separated extractant (to the left of the extracting vial, S1-S7).

\subsection{Standard and Sample Preparation}

Standards at $2000 \mathrm{ppm}$ concentration were ordered from Restek Corporation (Bellefonte, PA). The standards were diluted using $\mathrm{CH}_{2} \mathrm{Cl}_{2}$ to prepare a set of standards used for GC-MS/MS calibration. The extractant $\mathrm{CH}_{2} \mathrm{Cl}_{2}(>99.9 \%)$ was used for analysis with no further processing. Blank samples were used during calibration and sample analysis. Internal standards were added to each standard, sample, and blank.

\subsection{Standard and Sample Derivatization}

Derivatization was needed to better identify and quantify the following six compounds:

1. Ciprofloxacin HCL (86393-32-0)

2. Erythromycin USP (114-07-8)

3. Sulfamethoxazole (723-46-6)

4. Gemfibrozil (25812-30-0)

5. Naproxen (22204-53-1)

6. Ofloxacin (82419-36-1) 
N-Methyl-N-(trimethylsilyl)trifluoroacetamide (MSTFA) (Sigma-Aldrich Inc.) was used as the derivatizing agent. Briefly, the derivatizing process includes the following steps:

1. mix $0.2 \mathrm{~mL}$ of MSTFA with $0.2 \mathrm{~mL}$ of $\mathrm{CH}_{2} \mathrm{Cl}_{2}$

2. add $20 \mathrm{mg}$ of a compound to be derivatized

3. mix and place the mixture in an oven set at $60^{\circ} \mathrm{C}$ for $30 \mathrm{~min}$.

\subsection{Analytical Methods}

A GC-MS/MS system (Agilent 7000C) was used for the analysis (see Figure 3). Scan method was used to identify compounds by their mass spectra and to determine the retention times of the compounds in the samples. The selected ion monitoring (SIM) method was then used to measure a set of compounds. The multiple reactions monitoring (MRM) method was used to determine concentrations of compounds hard to determine using the SIM method.

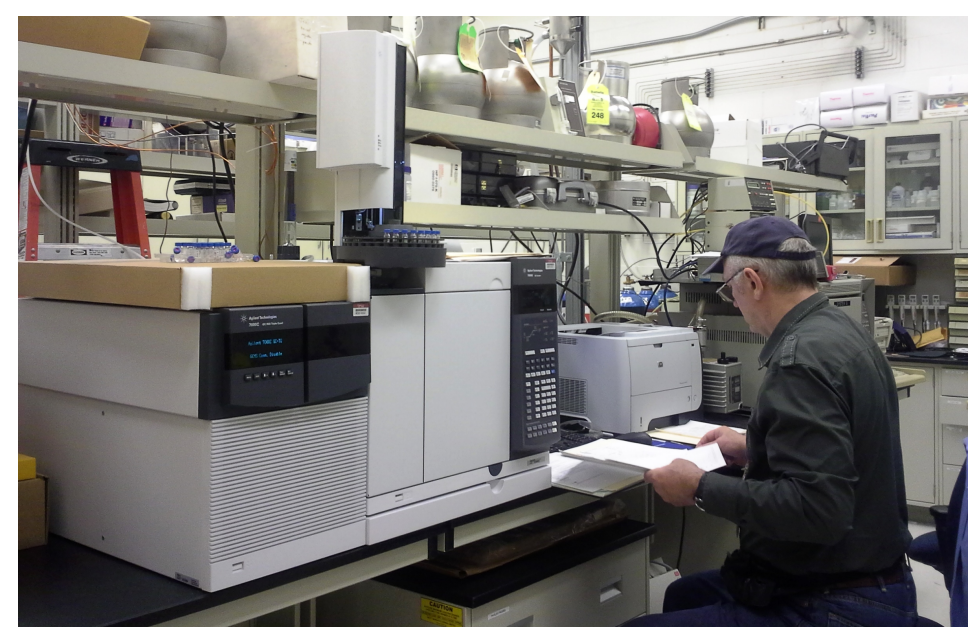

Figure 3. GC-MS/MS system used for analysis.

\subsubsection{Scan Method}

Scan method is the least sensitive, but most informative method. Every compound can be identified by its mass spectrum even without standards for those compounds. One sample (i.e., S-5) was screened using this method to evaluate the content of the samples and the sufficiency of chromatographic separation. The significant number of compounds was identified and the results are presented in Appendix A. The precise quantitation of those compounds cannot be determined without the standards. However, most were in the region of 1 to $100 \mathrm{ppm}$ in screened solution.

\subsubsection{SIM Method}

In this method the GC/MS registers only the characteristic ions for certain compound with retention times previously determined during the standards run. SIM method, which is 100 times more sensitive than scan method is sufficient for most of the compounds. In this work, samples were heavily loaded with organic materials, which produced significant interferences. In general, compounds with smaller molecular weights (MW) and shorter retention times (e.g., 4-tert-octylphenol) were reliably quantified. Compounds with larger MW in the second part of chromatogram had more significant interferences and MRM method was necessary. 


\subsubsection{MRM Method}

In this method the first mass spectrometer selects characteristic ions for certain compounds and the second mass spectrometer registers only the fragment ions for this selected characteristic ions after they are breaking in the collision cell, which is located between the two mass spectrometers. Thus, this method is more selective than SIM method. However, samples were complex and significant interferences were observed even using the MRM method.

\subsection{Results}

Results are presented in Table 3. Results highlighted in green are those with the highest degree of certainty. In some cases those results were confirmed by another method; however, in other cases another method was not necessary because the results were already reliable. Results highlighted in yellow are those where compounds were identified in the mixture, but the presence of significant interferences made quantification less certain than results with green highlights. Where there is no highlighting target compounds were not detected.

Duplicate samples were analyzed using complementary methods, i.e. SIM and MRM. The concentrations of quantifiable compounds from these methods correlated reasonably well, as indicated by the results from samples S3, S4, S6, and S7.

Ofloxacin was initially analyzed; however, after careful consideration, results were removed for this compound. The trimethylsilyl (TMS) derivative of 2,6-Bis(tert-butyl) phenol was observed in the product of Ofloxacin derivatization and in the samples-indicating this phenol could have been present in the original samples. Moreover, a pathway for how Ofloxacin could produce this phenol in derivatization process could not be determined.

The water samples (i.e., A-1 to A-3) were heavily loaded with organic matter, and the extractant of these samples was visually black - indicating the presence of organics. Only a few target compounds could be observed and quantified in these three samples. Most of the other target compounds could not be analyzed because of strong interferences from unidentified non-target compounds. However, this does not imply that the target compounds were not present.

Future analysis may require an alternate analytical approach for these kinds of samples. In addition, liquid chromatography-mass spectrometry (LC-MS) may be a better analytical tool for many of the target compounds.

Table 3a. Sample number and description.

\begin{tabular}{ll}
\hline Sample & Type \\
\hline S-1 & Wet Sludge \\
S-2 & Wet Sludge \\
S-3 & Wet Sludge \\
S-4 & Wet Sludge \\
S-5 & Wet Sludge \\
S-6 & Wet Sludge \\
S-7 & Wet Sludge \\
A-1 & Aqueous \\
A-2 & Aqueous \\
A-3 & Aqueous \\
\hline
\end{tabular}


Table 3b. Compound concentrations in sludge and aqueous samples. Concentration units: Sludge (S1-S7) -- $\mu \mathrm{g} / \mathrm{g}(\mathrm{mg} / \mathrm{kg})(\mathrm{ppm})$; aqueous sample (A1-A3) -- $\mu \mathrm{g} / \mathrm{ml}(\mathrm{mg} / \mathrm{L})(\mathrm{ppm})$

\begin{tabular}{ccccccccc}
\hline & 17-beta-Estradiol & \multicolumn{2}{c}{ 4-tert-octylphenol } & \multicolumn{2}{c}{ Acetaminophen } & \multicolumn{2}{c}{ Bis-phenol A } & Caffeine \\
\cline { 2 - 8 } Sample & SIM & SIM & MRM & SIM & MRM & SIM & MRM & SIM \\
\hline S-1 & ND & 0.06 & 0.06 & ND & 2.96 & 0.16 & 0.28 & ND \\
S-2 & ND & 0.07 & 0.06 & ND & 2.31 & 0.07 & ND & ND \\
S-3 & 1.55 & 0.13 & 0.18 & ND & ND & 11.97 & 2.69 & 2.11 \\
S-4 & 1.78 & 0.18 & 0.22 & ND & ND & 2.99 & 1.65 & 2.05 \\
S-5 & 0.50 & 0.24 & 0.32 & ND & 3.47 & 1.80 & 2.61 & 0.88 \\
S-6 & ND & 2.46 & 3.15 & ND & ND & 6.88 & 7.62 & 1.32 \\
S-7 & ND & 2.33 & 3.09 & ND & ND & 7.04 & 8.23 & 1.28 \\
A-1 & ND & ND & ND & ND & ND & ND & ND & ND \\
A-2 & ND & ND & 0.01 & ND & 0.21 & ND & ND & ND \\
A-3 & ND & ND & 0.05 & ND & ND & ND & ND & 0.66 \\
\hline
\end{tabular}

Deri.

\begin{tabular}{|c|c|c|c|c|c|c|c|c|c|c|}
\hline \multirow[b]{2}{*}{ Sample } & \multicolumn{2}{|c|}{ Carbamazepine } & \multicolumn{2}{|c|}{ Carmabazepine } & \multicolumn{2}{|c|}{ Diclophenac } & \multicolumn{2}{|c|}{ Estrone } & \multicolumn{2}{|c|}{ Ethynylestrad. } \\
\hline & SIM & MRM & SIM & MRM & SIM & MRM & SIM & MRM & SIM & MRM \\
\hline S-1 & ND & ND & ND & ND & ND & ND & ND & 0.15 & ND & ND \\
\hline S-2 & ND & ND & ND & ND & ND & ND & ND & ND & ND & ND \\
\hline S-3 & ND & ND & ND & ND & ND & ND & ND & 1.38 & ND & ND \\
\hline S-4 & ND & ND & ND & ND & ND & ND & ND & 0.97 & ND & ND \\
\hline S-5 & ND & ND & ND & ND & ND & ND & ND & 0.45 & ND & ND \\
\hline S-6 & ND & ND & ND & ND & ND & 0.025 & 0.64 & 0.72 & ND & ND \\
\hline S-7 & ND & ND & ND & ND & & ND & 0.16 & 0.20 & ND & ND \\
\hline A-1 & ND & ND & ND & 0.11 & ND & ND & ND & ND & ND & ND \\
\hline A-2 & ND & ND & ND & 0.03 & ND & ND & ND & ND & ND & ND \\
\hline A-3 & ND & ND & ND & 0.16 & ND & ND & ND & ND & ND & ND \\
\hline
\end{tabular}

\begin{tabular}{|c|c|c|c|c|c|c|c|c|c|c|}
\hline \multirow[b]{2}{*}{ Sample } & \multicolumn{2}{|c|}{ Fluoxetine } & \multicolumn{4}{|c|}{ Gemfibrozil } & \multicolumn{2}{|c|}{ Ibuprofen } & \multicolumn{2}{|c|}{ Naproxen } \\
\hline & SIM & MRM & & & MRM & Derivat. & SIM & MRM & SIM & Derivat. \\
\hline S-1 & ND & ND & & & ND & 0.29 & ND & ND & ND & 0.92 \\
\hline S-2 & ND & ND & & & ND & ND & ND & ND & ND & ND \\
\hline S-3 & ND & ND & & & ND & 0.07 & ND & 3.43 & ND & 1.26 \\
\hline S-4 & ND & ND & & & ND & 0.07 & ND & 4.04 & ND & 0.93 \\
\hline S-5 & ND & ND & & & ND & ND & ND & 3.35 & ND & ND \\
\hline S-6 & ND & ND & & & ND & ND & ND & 3.71 & ND & ND \\
\hline S-7 & ND & ND & & & ND & ND & ND & 3.87 & ND & ND \\
\hline A-1 & ND & ND & & & ND & ND & ND & ND & ND & ND \\
\hline A-2 & ND & ND & & & ND & ND & ND & ND & ND & ND \\
\hline \multirow[t]{2}{*}{ A-3 } & ND & ND & & & ND & ND & ND & ND & ND & ND \\
\hline & \multicolumn{2}{|c|}{ Primidone } & \multicolumn{2}{|c|}{ Progestrone } & \multicolumn{2}{|c|}{ Testosterone } & \multicolumn{2}{|c|}{ Triclosan } & \multicolumn{2}{|c|}{ Trimethoprim } \\
\hline Sample & SIM & MRM & SIM & MRM & SIN & MRM & SIM & MRM & SIM & MRM \\
\hline S-1 & ND & ND & ND & ND & 0.42 & ND & 0.51 & No data & 0.14 & No data \\
\hline S-2 & ND & ND & ND & ND & 0.17 & ND & 0.35 & No data & ND & No data \\
\hline S-3 & ND & ND & ND & ND & ND & ND & 5.43 & No data & 0.20 & No data \\
\hline S-4 & ND & ND & ND & ND & ND & ND & 5.90 & No data & 0.24 & No data \\
\hline S-5 & ND & ND & ND & ND & ND & ND & 7.86 & No data & 0.31 & No data \\
\hline S-6 & ND & ND & 1.61 & 1.93 & ND & ND & 16.75 & No data & 0.62 & No data \\
\hline S-7 & ND & ND & 1.22 & 1.40 & ND & ND & 15.65 & No data & 0.73 & No data \\
\hline A-1 & ND & ND & ND & ND & ND & ND & ND & No data & ND & No data \\
\hline A-2 & ND & ND & ND & ND & ND & ND & ND & No data & ND & No data \\
\hline A-3 & ND & ND & ND & ND & ND & ND & ND & No data & ND & No data \\
\hline
\end{tabular}

$\mathrm{ND}=$ not detected. 


\subsection{Summary}

The presence of organics complicated the analytical techniques and, in some cases, the precision of the results. However, residual concentrations of a range of compounds were detected in the wastewater sludge and the presence and concentrations of these compounds will be considered in identifying the appropriate handling of this material in conduct of research.

\subsection{Types of Compounds}

The types of compounds detected included common pain relievers, hormones and antibiotics, and plasticizers, which can also be endocrine disruptors. Highest concentrations were of Triclosan, which was found in all sludge samples ranging from 0.5 to $16.75 \mathrm{ppm}$. Triclosan is an antibacterial and antifungal agent found in consumer products, including soaps and detergents. Trimethoprim, a synthetic antibacterial, was detected in the sludge in concentrations ranging from 0.14 to $0.73 \mathrm{ppm}$ with the highest concentrations in S-6 and S-7. The compound, 4-tert-octylphenol, is used to manufacture alkylphenol ethoxylates, which are anionic surfactants used in detergents, industrial cleaners, and emulsifiers. It is also identified, as an endocrine disruptor. Another endocrine disruptor, Bis-phenol A, a plasticizer, was found in all sludge samples except S-2. The female hormone Progestrone was found in some samples, including S-6 and S-7, at concentrations ranging from 1.22 to $1.93 \mathrm{ppm}$. Estrone, another female hormone, was found in samples S-1, S-5, S-6, and S-7 with concentrations ranging from 0.15 to $1.38 \mathrm{ppm}$. Ibuprophen and Naproxen, anti-inflammatory pain relievers, were found in some sludge samples in the 3 to 4 ppm range for Ibuprophen and approximately the $1 \mathrm{ppm}$ range for Naproxen. Gemfibrozil, which is used to reduce cholesterol and triglycerides in the blood, was found in some samples in concentrations less than $1 \mathrm{ppm}$. Caffeine, a central nervous system stimulant, was also found in some samples (i.e., $0.66 \mathrm{ppm}$ in an aqueous sample and from 0.88 to $2.11 \mathrm{ppm}$ in sludge samples).

\subsection{Protection}

All detected compounds were in the "parts per million" range. To date, no occupational exposure limits have been identified for these compounds. However, the pharmaceutical industry recently developed personal protective equipment (PPE) guidelines. While the concentrations working directly with the nearly pure compound in the pharmaceutical industry are much higher than the residual concentrations in the wastewater sludge, it can be assumed that the exposure pathways for the compounds are similar and that the PPE identified by the pharmaceutical industry would be conservative if used for handling wastewater sludge. The PNNL worker health and safety representative will use the results in this report in combination with the pharmaceutical industry reports to identify the appropriate PPE for this work and will update the worker exposure assessment as applicable.

\subsection{References}

EPA-U.S. Environmental Protection Agency. 2009. Targeted National Sewage Sludge Survey Sampling and Analysis Technical Report. EPA-822-R-08-016, U.S. Environmental Protection Agency, Washington, DC.

Halling-Sorensen B., Nielsen S.N., Lanzky P.F., Ingerslev F., Holten-Lützhoft H.C., Jorgensen S.E. 1998. Occurrence, fate and effects of pharmaceutical substances in the environment - A review. Chemosphere 36:357-393. DOI:10.1016/S0045-6535(97)00354-8 
Mottaleb MA, MK Bellamy, MA Arafat Mottaleb, MR Islam. 2015. Use of LC-MS and GC-MS methods to measure emerging contaminants pharmaceutical and personal care products (PPCPs) in fish. J Chromatogr Sep Tech. 6:267. doi:10.4172/2157-7064.1000267.

Togola A and Budzinski H. 2007. Analytical development for analysis of pharmaceuticals in water samples by SPE and GC-MS. Anal Bioanal Chem. 388:627-635. DOI: 10.1007/s00216-007-1251-x

World Health Organization. 2011. Pharmaceuticals in Drinking-water. WHO/HSE/WSH/11.05 35p. 


\section{Appendix}

Compounds Identified During the Screening of S-5 Sample 



\section{Appendix}

\section{Compounds Identified During the Screening of S-5 Sample}

(Siloxanes were excluded because they are mostly coming from the column)

\begin{tabular}{|c|c|c|c|}
\hline $\mathrm{RT}$, min & Name & CAS & MW \\
\hline 6.05 & Phenol & $108-95-2$ & 94 \\
\hline 7.00 & D-Limonene & $5989-27-5$ & 136 \\
\hline 7.26 & Benzeneacetaldehyde & $122-78-1$ & 120 \\
\hline 7.51 & Benzene, n-butyl & $104-51-8$ & 134 \\
\hline 7.74 & p-Cresol & $106-44-5$ & 108 \\
\hline 7.96 & Benzenemethanethiol & $100-53-8$ & 124 \\
\hline 8.18 & 1,2,4-Trithiolane & $289-16-7$ & 124 \\
\hline 8.53 & Phenylethyl Alcohol & $60-12-8$ & 122 \\
\hline 8.76 & 1-Phenyl-1-butene & $1005-64-7$ & 132 \\
\hline 8.91 & $\mathrm{~N}$-(3-Methylbutyl)acetamide & $13434-12-3$ & 129 \\
\hline 9.35 & Benzene, pentyl- & $538-68-1$ & 148 \\
\hline 9.76 & 2-Piperidinone & $675-20-7$ & 99 \\
\hline 11.74 & Indole & $120-72-9$ & 117 \\
\hline 12.85 & Naphthalene,1,2,3,4-tetrahydro-1,1,6-trimethyl & $475-03-6$ & 174 \\
\hline 12.92 & n-Decanoic acid & $334-48-5$ & 172 \\
\hline 13.26 & 1H-Indole, 4- methyl & $16096-32-5$ & 131 \\
\hline 13.29 & 1H-Indole, 2- methyl & $95-20-5$ & 131 \\
\hline 13.61 & Naphthalene, 2,7-dimethyl- & $582-16-1$ & 156 \\
\hline 13.65 & Naphthalenol,-octahydro-4,8a-dimethyl & $19700-21-1$ & 182 \\
\hline 14.66 & 1H-Indole,2,3-dihydro-4-methyl & $62108-16-1$ & 133 \\
\hline 14.84 & Benzene, 1-(1,5-dimethyl-4-hexenyl)-4-methyl & $644-30-4$ & 202 \\
\hline 15.02 & Pentadecane & $629-62-9$ & 212 \\
\hline 15.25 & Acetamide, N-(2-phenylethyl)- & $877-95-2$ & 163 \\
\hline 15.62 & Benzene,(1-butylhexyl)- & $4537-11-5$ & 218 \\
\hline 15.75 & Benzene, (1-propylheptyl) & $4537-12-6$ & 218 \\
\hline 16.02 & Dodecanoic acid & $143-07-7$ & 200 \\
\hline 16.51 & Hexadecane & $544-76-3$ & 226 \\
\hline 16.87 & Tridecanoic acid & $638-53-9$ & 214 \\
\hline 17.02 & Benzophenone & $119-61-9$ & 182 \\
\hline 17.05 & Benzene, (1-butylheptyl) & $4537-15-9$ & 232 \\
\hline 17.19 & Benzene,(1-propyloctyl)- & $4536-86-1$ & 232 \\
\hline 17.49 & Benzene,(1-ethylnonyl)- & $4536-87-2$ & 232 \\
\hline 17.67 & n-Hexyl salicylate & $6259-76-3$ & 222 \\
\hline 17.91 & Heptadecane & $629-78-7$ & 240 \\
\hline 18.23 & 1-Tetradecanamine, N,N-dimethyl- & $112-75-4$ & 241 \\
\hline 18.35 & Benzene,(1-pentylheptyl)- & $2719-62-2$ & 246 \\
\hline 18.42 & Benzene, (1-butyloctyl) & $2719-63-3$ & 246 \\
\hline 18.58 & Benzene, (1-propylnonyl)- & $2719-64-4$ & 246 \\
\hline 18.85 & Tetradecanoic acid & $544-63-8$ & 228 \\
\hline 19.71 & Pentadecanoic acid & $1002-84-2$ & 242 \\
\hline
\end{tabular}




\begin{tabular}{|c|c|c|c|}
\hline $\mathrm{RT}, \min$ & Name & CAS & MW \\
\hline 19.95 & Caffeine & $58-08-2$ & 194 \\
\hline 20.28 & 1-Hexadecanol & $36653-82-4$ & 242 \\
\hline 20.48 & Homosalate & $118-56-9$ & 262 \\
\hline 21.23 & Palmitoleic acid & $373-49-9$ & 254 \\
\hline 21.30 & Pyrrolo(1,2-a0hexahydro-3-(2-methylpropyl) & $5654-86-4$ & 210 \\
\hline 21.56 & Hexadecanoic acid & $57-10-3$ & 256 \\
\hline 22.12 & Heptadecanoic acid & $506-12-7$ & 270 \\
\hline 22.29 & Cyclic octaatomic sulfur & $10544-50-0$ & 256 \\
\hline 23.27 & 1-Decanamine, N-decyl-N-methyl- & $7396-58-9$ & 311 \\
\hline 23.61 & 9-Octadecanoic acid & $112-79-8$ & 282 \\
\hline 23.82 & Octadecanoic acid & $57-11-4$ & 284 \\
\hline 23.87 & Pregnan-20-one $(5 \alpha)$ & $848-62-4$ & 302 \\
\hline 25.10 & Tricosane & $638-67-5$ & 324 \\
\hline 25.22 & Eicosylamine, N,N-dimethyl- & NIST\#:406305 & 325 \\
\hline 25.41 & N-Methyl-N-benzyltetradecanamine & $83690-72-6$ & 317 \\
\hline 26.04 & Pyrrolo[1,2-a]pyrazine-1,4-dione, hexahydro-3-(phenylmethyl)- & $14705-60-3$ & 244 \\
\hline 26.14 & Tetracosane & $646-31-1$ & 338 \\
\hline 27.13 & Pentacosane & $629-99-2$ & 352 \\
\hline 27.3 & Didodecyldimethylammonium bromide & $3282-73-3$ & 461 \\
\hline 27.64 & Phtalic acid, di(2-propenylpentyl) ester & NIST\#:377935 & 390 \\
\hline 28.06 & Hexacosane & $630-01-3$ & 366 \\
\hline 28.85 & Octocrylene & $6197-30-4$ & 361 \\
\hline 29.45 & 1,4-Benzenecarboxylic acid, bis(2-ethylhexyl)ester & $6422-86-2$ & 390 \\
\hline 30.18 & Squalene & $111-02-4$ & 410 \\
\hline 30.25 & Didecan-2-yl phtalate & $28029-89-2$ & 446 \\
\hline 30.87 & Cholesta-3,5-diene & $747-90-0$ & 368 \\
\hline 32.35 & Cholestan-3-ol & $360-68-9$ & 388 \\
\hline 32.53 & Stigmasta-3,5-diene & $79897-80-6$ & 396 \\
\hline 32.69 & Cholest-5-en-3-ol & NIST\#210384 & 386 \\
\hline 32.75 & Cholesterol & $57-88-5$ & 386 \\
\hline 32.83 & Cholestanol & $80-97-7$ & 388 \\
\hline 33.13 & Lathosterol & $80-99-9$ & 386 \\
\hline 33.18 & Cholest-14-en-3-ol & $20780-35-2$ & 386 \\
\hline 33.25 & Ergostanol & $6538-02-9$ & 402 \\
\hline 33.99 & Cholest-4-en-3-one & $601-57-0$ & 384 \\
\hline 34.21 & Stigmastanol & $19466-47-8$ & 416 \\
\hline 34.65 & $\gamma$-Sitosterol & $83-47-6$ & 414 \\
\hline 34.98 & Hexadecanoic acid, hexadecyl ester & $540-10-3$ & 480 \\
\hline 36.31 & $\gamma$-Sitostenone & 84924-96-9 & 412 \\
\hline 37.52 & Oleyl oleate & $3687-45-4$ & 532 \\
\hline
\end{tabular}





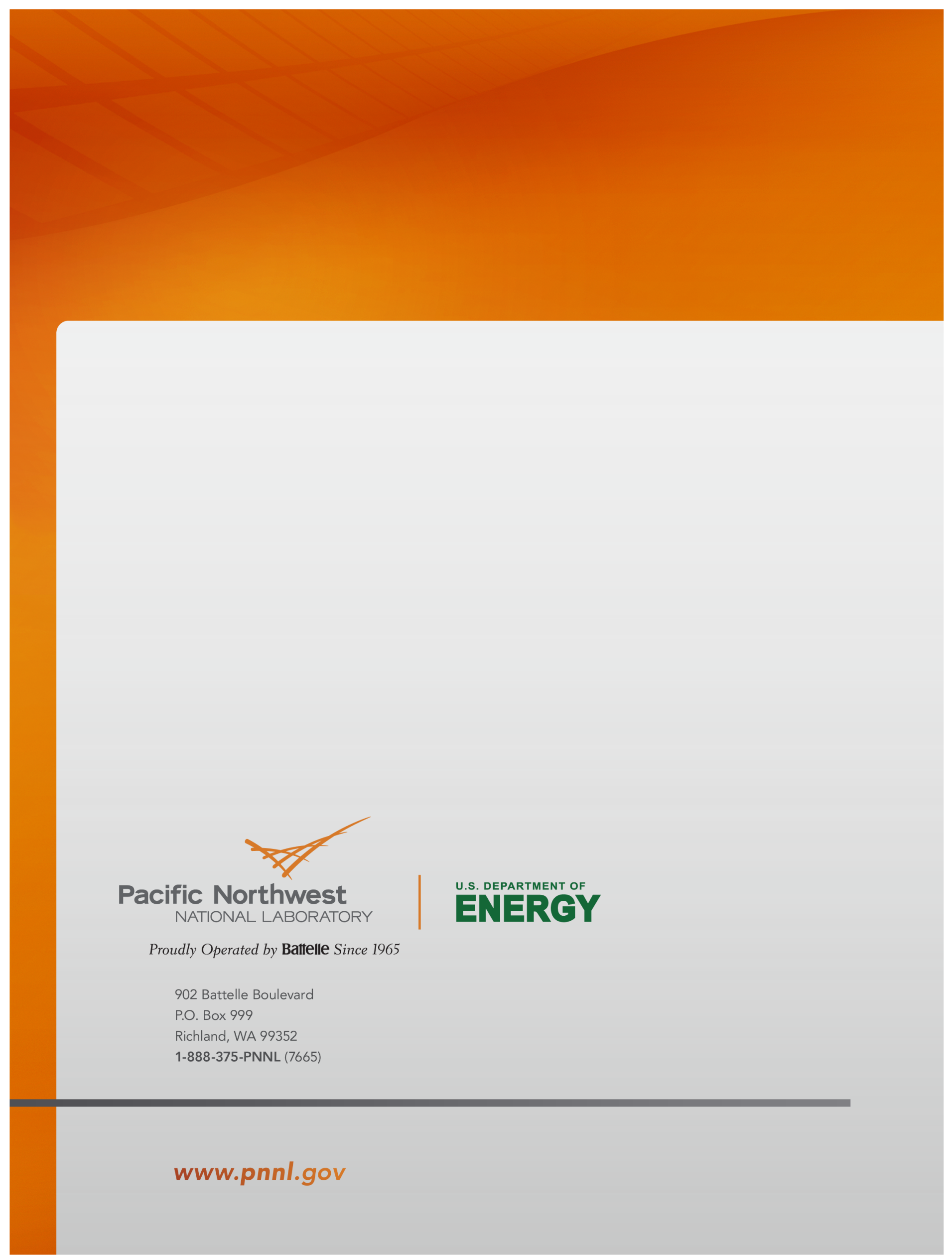

